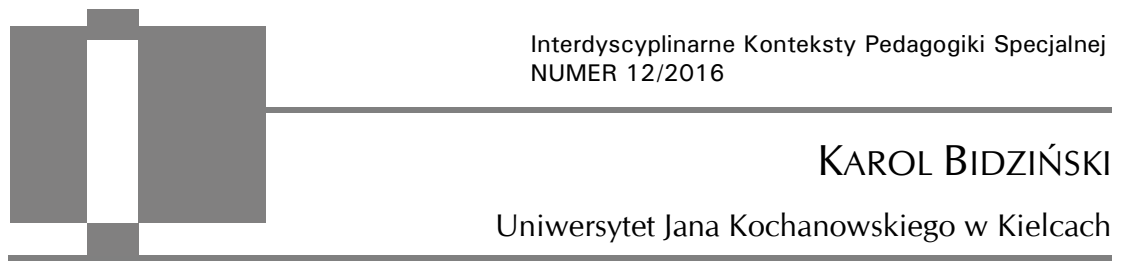

\title{
Szkoła ogólnodostępna jako środowisko odkrywania podstaw własnej tożsamości przez uczniów z niepełnosprawnością w młodszym wieku szkolnym
}

\begin{abstract}
Karol Bidziński, Szkoła ogólnodostępna jako środowisko odkrywania podstaw własnej tożsamości przez uczniów z niepetnosprawnościa w młodszym wieku szkolnym [A Mainstream School as an Environment of Discovering Attitudes of Their Own Identity by Disabled Pupils at an Early School Age]. Interdyscyplinarne Konteksty Pedagogiki Specjalnej, nr 12, Poznań 2016. Pp. 31-59. Adam Mickiewicz University Press. ISSN 2300-391X
\end{abstract}

On the basis of results of the contemporary researches realised according to the spirit of critical and emancipatory pedagogics a school appears not only as a very important, valuable environment of development, but unfortunately also as a place that generates different threads. In the article one has tried to show a significance of the mainstream school as an environment of discovering attitudes of one's own identity by the pupils with a disability at an early school age. Referring to the numerous empirical studies, one has performed a school discourse in order to show up discrimination practises in relation to this group of pupils. A critical analysis is accompanied by an attempt to indicate good practices of the socialising processes realised with regard to this group of persons in the mainstream school. A hope of the positive change is arisen by a Jarome S. Bruner's postulate to develop and implement a new, cooperative, educational culture of the school in which all subjects are concentrated on the common solving problems and launching a mutual learning process

Key words: identity formation, inclusive education, school for all, a person with a disability, emancipatory pedagogy 


\section{Wstęp}

W świetle przepisów prawa oświatowego ${ }^{1}$ uczniowie, których specjalne potrzeby edukacyjne wynikają z niepełnosprawności, mają prawo do kształcenia specjalnego. Może się ono odbywać w szkole specjalnej, integracyjnej lub ogólnodostępnej. Jak wynika z analiz danych statystycznych zamieszczonych w Systemie Informacji Oświatowej (SIO) oraz raportach Głównego Urzędu Statystycznego ${ }^{2}$ (GUS), uczniowie niepełnosprawni coraz częściej realizują obowiązek szkolny w placówkach ogólnodostępnych, zdecydowanie zmniejsza się liczba uczniów przebywających w szkołach segregacyjnych. Dane te mogą na pierwszy rzut oka napawać optymizmem, ukazując polski system oświaty jako otwarty dla uczniów z niepełnosprawnością i chroniący ich przed społeczną marginalizacją i wykluczeniem. Byłoby tak jednak dopiero wtedy, gdyby szkoła ogólnodostępna stanowiła dla uczniów z niepełnosprawnością przestrzeń realizacji ich specjalnych potrzeb edukacyjnych oraz prowadziła do pełnej społecznej integracji. Na ile polska szkoła jest takim wartościowym środowiskiem edukacyjnym? Inspiracji do poszukiwania odpowiedzi na to ważne społecznie pytanie warto poszukać w dorobku teoretycznym i metodologicznym pedagogiki specjalnej, krytycznej i emancypacyjnej ${ }^{3}$.

Współczesna pedagogika emancypacyjna zachęca do poszukiwania w aktualnych procesach edukacyjnych „mechanizmów zbiorowego i indywidualnego wyzwolenia jednostki, przy jednoczesnym piętnowaniu mechanizmów zniewalających, podporządkowujących

1 Ustawa o systemie oświaty z dnia 7 września 1991 r. (Dz.U. z 1991 r. Nr 95, poz. 425).

2 Raport GUS Oświata $i$ wychowanie w roku szkolnym 2010/11, http://stat.gov. pl/cps/rde/xbcr/gus/e_oswiata_i_wychowanie_2010-2011.pdf [12.07.2015]; System Informacji Oświatowej (SIO) rok szkolny 2014/15 publikowanych na stronie Centrum Informatycznego Edukacji http://www.cie.men.gov.pl/index.php/dane-sta tystyczne/139.html) [12.07.2015].

${ }^{3}$ A. Krause, Teoretyczne inspiracje pedagogiki specjalnej - pedagogika emancypacyjna, „Studia Edukacyjne” 2013, nr 28, s. 6-15. 
i ograniczających jej rozwój"4. Ich wykrycie może stać się pierwszym krokiem prowadzącym do wyzwolenia osób zagrożonych społeczną marginalizacją i wykluczeniem. Założenia pedagogiki emancypacyjnej $\mathrm{w}$ pewnym zakresie zbieżne są $\mathrm{z}$ pedagogiką specjalną, w której paradygmat podmiotowości i autonomii człowieka z niepełnosprawnością, jego prawo do samostanowienia i optymalnego rozwoju od lat wypełnia przestrzeń rozważań teoretycznych i stanowi cel długofalowych działań praktycznych 5 .

Poważną inspiracją dla działań pedagogicznych w zakresie kształcenia i wychowania uczniów z niepełnosprawnością mogą być wyprowadzone z pedagogiki emancypacyjnej poglądy na temat celów edukacji, istoty zmian i oddziaływań edukacyjnych; metod, środków i form wychowania oraz nowej roli nauczycieli w tych procesach ${ }^{6}$. Oparta na tych założeniach szkoła może stać się miejscem wzrastania dziecka z zaburzeniami rozwojowymi wolnym od depersonalizacji i degradujących doświadczeń. Jednocześnie może wyposażyć je w tak potrzebne w dorosłym życiu kompetencje emancypacyjne (świadomość własnych praw, dążenie do ich pozyskania, wrażliwość na ograniczenia i opresje oraz inne).

Analizując sytuację uczniów z niepełnosprawnością w szkole ogólnodostępnej, warto odwoływać się do wyników badań ukazujących wybrane aspekty funkcjonowania współczesnej szkoły. Oparte na nowych teoretyczno-metodologicznych podstawach badania odsłaniają niepokojący obraz. „Jak bowiem wynika z licznych analiz, należy zacząć mówić już nie o funkcjach i celach edukacji wczesnoszkolnej, lecz o jej niekorzystnych rozwojowo skutkach i szkodliwym wpływie na dzieci"7.

Przez długie lata badacze poszukiwali źródeł trudności rozwojowych i edukacyjnych głównie we właściwościach dziecka oraz

${ }^{4}$ Ibidem, s. 8.

${ }^{5}$ A. Krause, Wspótczesne paradygmaty pedagogiki specjalnej, Oficyna Wydawnicza „Impuls”, Kraków, 2010, s. 198-210.

${ }^{6}$ M. Czerepaniak-Walczak, Pedagogika emancypacyjna, rozwój świadomości krytycznej człowieka, Gdańskie Wydawnictwo Psychologiczne, Gdańsk 2006, s. 79-80.

${ }^{7}$ D. Klus-Stańska, Wprowadzenie do ksiażki, [w:] (Anty)edukacja wczesnoszkolna red. D. Klus-Stańska, Oficyna Wydawnicza „Impuls”, Kraków 2014, s. 16. 
cechach jego środowiska rodzinnego. Jako przyczynę problemów wskazywano zły stan zdrowia, niepełną sprawność dziecka, zaniedbania środowiskowe i inne. Stosunkowo rzadko poddawano krytycznej ocenie działalność instytucji oświatowych, zakładając dość naiwnie ich organizacyjną i realizacyjną doskonałość.

Wśród badaczy praktyki szkolnej, pedagogów, psychologów i socjologów edukacji powszechna jest świadomość istotnego znaczenia dobrze zorganizowanej wczesnej edukacji dla rozwijającego się człowieka. Na podstawie wyników współczesnych badań realizowanych w duchu pedagogiki krytycznej i emancypacyjnej szkoła jawi się nie tylko jako bardzo ważne, wartościowe środowisko rozwoju, ale niestety także jako miejsce generujące liczne zagrożenia. $\mathrm{W}$ badaniach istotne jest poznawanie nie tylko jawnych, ale także tych ukrytych wzorów wewnątrzszkolnej kultury. Dotarcie do nich możliwe jest poprzez wnikliwą analizę „codzienności szkolnej” jako kategorii doświadczania świata społecznego przez nauczycieli oraz inne podmioty 8 . Poznanie organizacji systemu i funkcjonowania konkretnych instytucji oświatowych może stać się punktem wyjścia do ich usprawniania i tym samym ochrony uczniów przed niekorzystnym oddziaływaniem nieefektywnej edukacji. W działaniach tych szkoła potrzebuje płynącego od naukowców wsparcia w tworzeniu edukacyjnej wspólnoty i etycznego zaangażowania w kształtowanie międzyludzkich relacji, w których konstruowane są tożsamości jednostek.

W artykule tym starano się ukazać znaczenie szkoły ogólnodostępnej jako środowiska odkrywania podstaw własnej tożsamości przez uczniów z niepełnosprawnością w młodszym wieku szkolnym.

${ }^{8}$ A. Schútz, O wielości światów. Szkice z socjologii fenomenologicznej, Wydawnictwo Naukowe Nomos, Kraków 2008, s. 37; M. Grochowalska, Codzienność świata społecznego szkoły kontekstem doświadczania napięć przez nauczycieli edukacji wczesnoszkolnej, [w:] Szkoła jako przestrzeń edukacyjnego (nie)porozumienia, red. A. Domagała-Kręcioch i B. Majerek, Oficyna Wydawnicza „Impuls”, Kraków 2014, s. 61-76; S. Sadowska, Praktyka tworzenia edukacyjnej wspólnoty - o edukacyjnej codzienności w kontekście jawnych i ukrytych wzorów kultury szkolnej, „Studia Edukacyjne” 2015, nr 34, s. 71-88. 


\section{Rozważania na temat pojęcia tożsamość - trud definiowania}

Tożsamość stała się przedmiotem zainteresowań wielu dyscyplin, ale mimo dużej ilości prac teoretycznych i empirycznych nadal pozostaje pojęciem wieloznacznym, różnie interpretowanym ${ }^{9}$. Lech Witkowski przestrzega przed bezrefleksyjnym i zbyt powierzchownym traktowaniem tej kategorii pojęciowej. Zdaniem autora, rozwiązaniem tego terminologicznego problemu może być próba konsolidacji pojęcia wokół tzw. „krytycznej” strategii poznawczej inspirowanej pracami J. Habermasa oraz pogłębiona analiza koncepcji tożsamości Erika Eriksona.

Autor wskazuje triadę, wyznaczającą trójzakresową "bazę epistemologiczną" pojęcia tożsamości:

1) poczucie tożsamości jako bezwiednej kondycji „,ja”,

2) tożsamości umiejscowień jako koncepcji siebie w świecie

3) i wreszcie tożsamości w zakresie kompetencji do działania, czyli formalnej struktury możliwego kontaktu ze światem ${ }^{10}$.

W rozważaniach teoretycznych i badaniach empirycznych istotne jest precyzyjne określanie sposobu definiowania tego złożonego pojęcia. Spośród wielu koncepcji szczególnie interesujące są te, które traktują tożsamość jako proces, a nie stan, będący rezultatem tego procesu. Tak określa to pojęcie Aldona Jawłowska: „Owa »tożsamość« jest raczej postulatem, celem, niż właściwością, sytuacją niż trwałym stanem posiadania. Inaczej mówiąc, ma ona zawsze charakter relacyjny i twórczy"11. Kształtowanie tożsamości jest procesem wymagającym aktywności i kreatywności jednostki, a jednocześnie odbywając się w zmieniającym się kontekście społecznym, wymaga stałej gotowości do budowania relacji z innymi. Na dynamiczny charakter procesu kształtowania tożsamości człowieka

${ }^{9}$ Z. Bokszański, Tożsamości zbiorowe, Wydawnictwo PWN, Warszawa, 2008.

${ }^{10}$ L. Witkowski, Rozwój i tożsamość w cyklu życia. Studium koncepcji Erika H. Eriksona, Wydawnictwo UMK, Toruń 1989, s. 146.

11 A. Jawłowska, Tożsamość na sprzedaż, [w:] Wokót problemów tożsamości, red. A. Jawłowska, Wydawnictwo LTW, Warszawa 2001, s. 54. 
zwraca uwagę także L. Witkowski, który w następujący sposób opisał ten proces:

Odbywa się to nie poprzez kontemplację, lecz w życiowym kontakcie (o różnej intensywności i skali) człowieka ze światem, w trakcie jego doświadczania, często dolegliwego, niezbornego i niespójnego, radykalnie ingerującego $\mathrm{w}$ uznane przez jednostkę obrazy świata, siebie samego i relacje ja - inni ${ }^{12}$.

Ważną rolę $\mathrm{w}$ kształtowaniu tożsamości odgrywają procesy identyfikacyjne, wyrażające sposób odnoszenia się jednostki do otoczenia. Procesy te to: identyfikacja rozumiana jako rozpoznanie otoczenia jako tła dla własnych zachowań; identyfikacja jako odzwierciedlenie oczekiwań istniejących $\mathrm{w}$ społecznym otoczeniu jednostki; identyfikacja jako idealizacja czyli projekcyjny proces powstawania obrazu , ja" idealnego ${ }^{13}$.

Doświadczanie licznych utrudnień i ograniczeń w aktywności społecznej wynikających z niskiej sprawności fizycznej, psychicznej, umysłowej lub funkcjonowania zmysłów stanowi poważne zagrożenie dla procesów identyfikacyjnych. W skrajnych przypadkach głębokość uszkodzeń centralnego układu nerwowego uniemożliwia jednostce poznawcze wyodrębnienie siebie z tła, poważnie zaburza kształtowanie poczucia własnej tożsamości i uniemożliwia stworzenie koncepcji siebie. Osoby z niepełnosprawnością intelektualną głębszego stopnia $\mathrm{z}$ powodu poważnych ograniczeń $\mathrm{w}$ funkcjonowaniu poznawczym napotykają na trudności w tworzeniu reprezentacji ,ja”, a formułowanie tożsamości u tych osób dokonuje się tylko na poziomie elementarnym. Jednak bogactwo społecznych doświadczeń zapewnione im przez otoczenie $\mathrm{w}$ kolejnych etapach życia może w pewnym stopniu kompensować niedostatki poznawcze oraz stopniowo prowadzić do emancypowania się tych osób i kształtowania zrębów osobistej tożsamości ${ }^{14}$.

12 L. Witkowski, Tożsamość i zmiana: epistemologia i rozwojowe profile w edukacji, Wydawnictwo Naukowe Dolnośląskiej Szkoły Wyższej, Wrocław 2010, s. 142.

13 Ibidem, s. 148. Por. Graumann.

14 D. Kopeć, Odkrywanie siebie przez osobę z głęboka niepetnosprawnością w kontekście teorii wczesnego rozwoju poczucia siebie Daniela Sterna, [w:] O poznawaniu siebie 
Złożoność i niepowtarzalność przebiegu procesu kształtowania tożsamości każdej jednostki ludzkiej oraz wielowymiarowość doświadczania niepełnej sprawności utrudnia pełne ukazanie związku między tymi fenomenami. Sytuację dopełnia możliwość analizowania problemu kształtowania tożsamości przez osoby niepełnosprawne w odwołaniu do różnorodnych koncepcji teoretycznych wyprowadzonych ze współczesnej pedagogiki, psychologii, socjologii. Inaczej koncepcję wychowania i problem kształtowania tożsamości ujmują teorie wyprowadzone $\mathrm{z}$ pedagogiki rozumianej $\mathrm{w}$ perspektywie orientacji strukturalistycznej inaczej post-strukturalistycznej ${ }^{15}$. Szczególnie przydatną do tego typu analiz może być teoria interakcjonizmu symbolicznego ${ }^{16}$. Jej twórcy zakładają, że proces kształtowania tożsamości odbywa się w ścisłym związku z otoczeniem społecznym, a jego podstawę stanowią dialogowe interakcje społeczne. Do opisu sytuacji kreowania tożsamości przez osoby niepełnosprawne wykorzystać można także teorie społecznego naznaczenia spopularyzowane przez Erwina M. Lemerta, Johna I. Kitsue i Howarda S. Beckera oraz teorię społecznego piętna Ervinga Goffmana ${ }^{17}$. Stanowić mogą one doskonały punkt odniesienia do analizy procesów tworzenia stereotypów i stygmatyzowania jednostek odmiennych oraz ich społecznego naznaczenia i „zmuszania” do przyjęcia

i świata przez dziecko ze specjalnymi potrzebami edukacyjnymi, red. W. Pilecka, K. Bidziński, M. Pietrzkiewicz, Wydawnictwo Uniwersytetu Humanistyczno-Przyrodniczego Jana Kochanowskiego, Kielce 2008, s. 67-74; D. Kopeć, Rzeczywistość (nie)edukacyjna osoby $z$ głęboka niepetnosprawnościa intelektualną. Zbiorowe instrumentalne studium przypadku, Wydawnictwo Naukowe UAM, Poznań 2013; M. Kościelska, Oblicza upośledzenia, PWN, Warszawa 1995; B. Cytowska, Trudne drogi adaptacji. Wątki emancypacyjne w analizie sytuacji dorostych osób z niepetnosprawnościa intelektualna we wspótczesnym społeczeństwie polskim, Oficyna Wydawnicza „Impuls”, Kraków 2013.

${ }^{15}$ J. Rzeźnicka-Krupa, Niepetnosprawność $i$ świat społeczny. Szkice metodologiczne, Oficyna Wydawnicza „Impuls”, Kraków 2009, s. 60.

${ }^{16} \mathrm{H}$. Blumer, Społeczeństwo jako symboliczna interakcja, [w:] Kryzys i schizma. Antyscjentyczne tendencje w socjologii wspótczesnej, red. E. Mokrzycki, PIW, Warszawa 1984, s. 71-86.

${ }^{17}$ A. Kojder, Co to jest teoria naznaczenia spotecznego?, "Studia Socjologiczne" 1980, nr 3 (78) www.ipsir.uw.edu.pl/.../AKojder4Co\%20to\%20jest\%20teoria\%20 naznac [24.03.2015]. 
określonej roli. Natomiast teoria reprodukcji społecznej P. Bourdieu i J.C. Passerona ${ }^{18}$ może dawać solidną podstawę dla krytyki współczesnej szkoły jako środowiska przemocy symbolicznej. Wśród różnorodnych psychologicznych koncepcji człowieka na uwage zasługuje teoria E.H. Eriksona ${ }^{19}$ traktująca proces kształtowania tożsamości jako budowanie relacji z samym sobą oraz innymi ludźmi analizowany $\mathrm{w}$ ujęciu biograficznym oraz wyprowadzone $\mathrm{z}$ psychologii społecznej teorie zgodności poznawczej, atrybucji, porównań społecznych ${ }^{20}$. Ze względu na dość powszechną znajomość wymienionych koncepcji tylko skrótowo omówione zostaną niektóre z nich, do kolejnych zaś nawiążę w dalszych częściach tekstu.

Zgodnie $\mathrm{z}$ założeniami symbolicznego interakcjonizmu (por. G.H. Mead, H. Blumer i inni) „jednostka w toku życia przyswaja sobie różne perspektywy oglądu samej siebie, postrzega własną osobę tak, jak odbierają ją inni uczestnicy życia społecznego"21. Szczególna rola w tym procesie przypada społecznej komunikacji, za pomocą której dochodzi do kontaktów i interakcji jednostki ze światem. W toku interakcji społecznych za pomocą języka współtworzony jest dyskurs stanowiący przestrzeń wspólnie podzielanych znaczeń. Dyskurs ma także „moc kształtowania relacji i praktyk społecznych, konstruowania wiedzy na temat rzeczywistości oraz społecznych tożsamości jednostek i grup poprzez lokalizowanie ich w określonych strukturach sieci znaczen" ${ }^{22}$.

A.L. Strauss wymienia „trzy podstawowe mechanizmy formowania się tożsamości: autodefinicję aktora społecznego, sposób jego definiowania przez innych oraz treści wzajemnie przekazywanych sobie przez uczestników interakcji”23. Badacz ten wskazuje także na

18 P. Bourdieu, J.C. Passeron, Reprodukcja. Elementy teorii systemu nauczania, Wydawnictwo Naukowe PWN, Warszawa 2006.

${ }^{19}$ E.H. Erikson, Dzieciństwo i społeczeństwo, Wydawnictwo Rebis, Poznań 2000.

${ }^{20}$ K. Błeszyńska, Niepetnosprawność a struktura identyfikacji społecznych, Wydawnictwo Akademickie „Żak”, Warszawa 2001 s. 30-41.

${ }^{21}$ J. Rzeźnicka-Krupa, Niepetnosprawność $i$ świat społeczny..., s. 19.

22 Ibidem, s. 23.

${ }^{23}$ K. Błeszyńska, op. cit., s. 25. 
potencjalne źródła zaburzeń $\mathrm{w}$ procesie formowania się i przekształcania tożsamości. Zalicza do nich fiksację na wybranym statusie danej osoby (np. status osoby przewlekle chorej); zmuszanie jednostki do przyjęcia określonego statusu; kierowanie pod adresem jednostki przepowiedni i inne.

Na podobny aspekt $\mathrm{w}$ kreowaniu tożsamości zwraca uwagę A. Jawłowska. Autorka analizuje problem, który można określić jako „dramat uznania”. Przytacza poglądy Taylora:

od chwili gdy aspirujemy do samookreślenia, zwłaszcza oryginalnego, pojawia się potencjalna niezgodność między istnieniem, do którego pretendujemy, a istnieniem, które inni gotowi są nam przyznać. Jest to przestrzeń uznania, które się dopominamy, ale którego inni mogą nam odmówić24.

Jak zauważa S. Tucker:

Niewiele jest modeli ról czy też subkultur, z którymi osoby niepełnosprawne mogłyby się identyfikować i które pomogłyby im w integracji, gdyż sztywne standardy stawiane wobec osób pełnosprawnych są przeceniane, przypisuje się im tak wiele wartości, że osobie niepełnosprawnej już z samej definicji nie może się powieść...25.

Społeczeństwo przypisuje osobom, których rozwój odbiega od normy, rolę człowieka niepełnosprawnego. Odwołując się do szeregu badań, K. Błeszyńska wymienia atrybuty tej roli:

Od osób niepełnosprawnych oczekuje się specyficznych wzorów zachowań i karier życiowych. Narzuca się im postawy żalu, bierność, submisyjność, automarginalizację, rezygnację z kierowania własnym życiem. We wzorach karier życiowych eksponuje się pozostawanie w kręgu oddziaływań rodziny pochodzenia oraz instytucji religijnych, charytatywnych i opiekuńczych ${ }^{26}$.

24 A. Jawłowska, op. cit., s. 56.

${ }^{25} \mathrm{~J}$. Kirenko, Niektóre uwarunkowania psychospołecznego funkcjonowania osób z uszkodzeniem rdzenia kręgowego, Wydawnictwo UMCS, Lublin 1995, s. 59.

${ }^{26}$ K. Błeszyńska, op. cit., s. 106. 
Zgodnie z koncepcją K.J. Tillmanna aktywizacja tej roli odbywa się $\mathrm{w}$ procesie socjalizacji, $\mathrm{w}$ trzech fazach. Pierwsza, tzw. socjalizacja pierwotna, odbywa się na terenie wychowującej dziecko rodziny. Jej efekty w znacznym stopniu rzutują na dalszy bieg procesu. Druga przypada na okres nauki szkolnej (socjalizacja wtórna), trzecia faza (socjalizacja trzeciego rzędu) przypisywana jest okresowi dorosłości i samodzielności jednostki27.

Kwestie wiążące się z esencjalistycznymi i nieesecjalistycznymi koncepcjami ujmowania tożsamość jednostek na tle rozważań dotyczących problematyki zjawiska niepełnosprawności i społeczno-kulturowych procesów konstruowania tożsamości osób niepełnosprawnych bardzo szczegółowo omawia $\mathrm{w}$ swoich pracach J. Rzeźnicka-Krupa ${ }^{28}$.

Z perspektywy psychologii na szczególne uznanie zasługuje koncepcja tożsamości opracowana przez Erika Eriksona ${ }^{29}$. Autor opisał osiem podstawowych kryzysów psychospołecznych, z których każdy stanowi zwrotny punkt $w$ rozwoju tożsamości człowieka. Kryzysy te to stojące przed jednostką w kolejnych okresach życia zadania lub dylematy psychologiczne, których źródła tkwią w oczekiwaniach społecznych. Rozwój tożsamości odbywa się w teatrze życia społecznego, w kontakcie $\mathrm{z}$ ważnymi osobami, w najbliższym otoczeniu.

Uzyskanie $\mathrm{w}$ dzieciństwie ogólne poczucie bezpieczeństwa, optymizm, zaufanie do innych; autonomia i ufna samodzielność $\mathrm{w}$ pokonywaniu przeszkód; inicjatywa związana z poznawaniem środowiska oraz wynikająca $\mathrm{z}$ wiary we własne siły przedsiębiorczość stanowią ważne osiągnięciami w kształtowaniu tożsamości dziecka. Są one podstawą, aby w dalszych etapach życia jednostka mogła pozytywnie rozwiązać kolejne dylematy rozwojowe. Kształ-

27 K. Błeszyńska, op. cit., s. 103.

28 J. Rzeźnicka-Krupa, Niepetnosprawność $i$ świat społeczny...; J. Rzeźnicka-Krupa, Tożsamość i wykluczenie. Fenomen niepetnosprawności na marginesach ludzkiej egzystencji?, [w:] Obszary społecznej marginalizacji - niepetnosprawność, red. J. Rutkowiak i A. Krause, Wydawnictwo OSW, Olsztyn 2009.

${ }^{29}$ E.H. Erikson, op. cit. 
towanie tożsamości odbywa się początkowo $\mathrm{w}$ środowisku rodzinnym $^{30}, \mathrm{z}$ czasem dziecko rozpoczyna nawiązywać interakcje $\mathrm{z}$ innymi osobami. Ważnym miejscem socjalizacji staje się placówka edukacyjna: przedszkole, a następnie szkoła. Na niekorzystne dla kształtowania tożsamości uczniów oddziaływania współczesnej, transmisyjnej szkoły zwraca uwagę M. Szczepska-Pustkowska. Autorka w swoich analizach wykorzystała teorię tożsamości E. Eriksona ${ }^{31}$.

Nieprawidłowo realizowane wczesne działania edukacyjno-terapeutyczne lub zaniechania $\mathrm{w}$ tym zakresie stanowią bardzo poważny czynnik ryzyka dla kształtującej się tożsamości dziecka niepełnosprawnego rozpoczynającego edukację szkolną. W naszym kraju brakuje systemowych rozwiązań prowadzących do objęcia wczesną pomocą i wsparciem dzieci z zaburzeniami rozwoju i ich rodzin. Mimo podejmowanych prób zmiany tego stanu rzeczy ${ }^{32}$, nadal pomoc ta przybiera formę nieskoordynowanych, niesystematycznych, niedostatecznie finansowany i przez to trudno dostępnych i mało efektywnych działań. Konsekwencje zaniedbań w tym zakresie w znaczący sposób wpływają na realizację kolejnych zadań rozwojowych. Wiele zastrzeżeń budzi także proces edukacyjnego

${ }^{30}$ K. Bidziński, Rodzina jako prymarny kontekst rozwojowy jednostki, [w:] Dziecko ze specjalnymi potrzebami edukacyjnymi $w$ drodze ku dorostości, red. W. Pilecka, M. Rutkowski, Oficyna Wydawnicza „Impuls”, Kraków 2009, s. 232-237 - opisano rolę rodziny dziecka niepełnosprawnego w kształtowaniu jego tożsamości

${ }^{31}$ M. Szczepska-Pustkowska, Szkolna petryfikacja rodzacej się tożsamości dziecka, [w:] (Anty)edukacja wczesnoszkolna..., s. 204-224.

${ }^{32}$ Zrealizowany w latach 2005-2007 pilotażowy program rządowy „Wczesna, Wielospecjalistyczna, Kompleksowa, Skoordynowana i Ciągła Pomoc Dziecku Zagrożonemu Niepełnosprawnością lub Niepełnosprawnemu oraz Jego Rodzinie", https:// archiwum.men.gov.pl/index.php?option=com_content\&view $=$ article\&id $=446 \% 3 \mathrm{Aq}$ wczesna-wielospecjalistyczna-kompleksowa-skoordynowana-i-ciga-pomoc-dzieckuzagroonemu-niepenosprawnoci-lub-niepenosprawnemu-oraz-jego-rodzinieq\&catid= 118\%3Aycie-szkoy-pomoc-psychologiczno-pedagogiczna\&Itemid=155 [23.02.2015], a następnie w latach 2008-2012 program „Wczesna Pomoc Dziecku Niepełnosprawnemu (Raport końcowy WPDN); https://www.pfron.org.pl/ftp/dokumenty/Bada nia_i_analizy/Raport_koncowy_WPDN_ostateczny.pdf [23.02.2015]. 
przygotowania dziecka do podjęcia zadań szkolnych ${ }^{33}$. Problem ten nabiera szczególnego znaczenia, jeśli dotyczy dziecka, które w związku ze specyfiką swojego rozwoju potrzebuje więcej czasu i starannie przemyślanych działań edukacyjno-terapeutycznych wspierających jej w uzyskaniu gotowości do podjęcia nauki szkolnej.

\section{Krytyczna analiza szkolnego dyskursu - demaskowanie praktyk dyskryminacyjnych wobec uczniów doświadczających niepełnosprawności}

Dla dziecka rozpoczynającego edukację szkolną szczególnego znaczenia nabierają interakcje $\mathrm{z}$ innymi niż rodzic dorosłymi, a przede wszystkim wzajemne kontakty z rówieśnikami. Jest to okres, w którym potrzeba bycia z rówieśnikami stopniowo zaczyna konkurować z kontaktami z dorosłymi ${ }^{34}$. Relacja dziecka z rodzicami bywa zwykle oparta na silnych uczuciach miłości i przywiązania, ukierunkowana jest na realizację dziecięcych potrzeb. Kontakty z rówieśnikami mają inny charakter (symetryczny, poziomy). $\mathrm{W}$ tych interakcjach spotykają się dwa równoprawne podmioty, często bardzo mocno skupione na swoich osobistych potrzebach, od obu w jednakowym stopniu zależy jakość interakcji ${ }^{35}$.

Wejście do przestrzeni edukacyjnej szkoły jest szczególnie trudnym doświadczeniem dla dzieci, których stan zdrowia i rozwoju

33 D. Waloszek, Między przedszkolem a szkoła. Rozważania o gotowości dzieci do podjęcia nauki w szkole, Wydawnictwo Akademickie Żak, Warszawa 2014.

34 B. Bieleń, Rówieśnik - partner w rozwoju, [w:] Pedagogika małego dziecka wybrane zagadnienia, red. M. Karwowska-Struczyk, E. Słodownik-Rycaj, Instytut Badań Edukacyjnych, Warszawa 2007, s. 71-76.

35 Zwrócono na to uwagę w artykule, w którym dokonano przeglądu badań oraz zaobserwowanych dobrych praktyk dotyczących pozytywnej roli, jaką może odegrać grupa rówieśnicza w socjalizacji dzieci i młodzieży z cechami autyzmu w ogólnodostępnych placówkach edukacyjno-wychowawczych K. Bidziński, Rola szkoty w ksztatceniu aksjologicznym dzieci w młodszym wieku szkolnym, [w:] Doświadczanie poznawania świata przez dzieci w młodszym wieku szkolnym, red. I. Adamek, B. Pawlak, Wydawnictwo Libro, Kraków 2012, s. 143-164. 
generuje specjalne potrzeby w zakresie społecznego funkcjonowania. Sygnałem świadczącym o nasileniu tych potrzeb są ujawniane trudności w zakresie komunikacji, czynnościach samoobsługowych, w sferze przeżyć emocjonalnych. Jednym z poważnych problemów doświadczanych przez dzieci jest brak zdolności tolerowania czasowej, wynikającej z konieczności realizacji obowiązku edukacyjnego, separacji od rodziców. Dotyczy on zwłaszcza tych dzieci, które doświadczają zaburzeń $\mathrm{w}$ rozwoju więzi emocjonalnych $\mathrm{z}$ osobą znaczącą ${ }^{36}$. Najwięcej trudności w społecznym funkcjonowaniu obserwuje się u dzieci, u których zdiagnozowano całościowe zaburzenia rozwoju ze spektrum autyzmu lub niepełnosprawność o charakterze sprzężonym. Często szkoła ogólnodostępna nie jest wstanie odpowiedzieć na specjalne potrzeby rozwojowe i edukacyjnej tych uczniów. O braku skuteczności działań integrujących może świadczyć fakt, że uczniowie z autyzmem, którzy trafiają do szkół ogólnodostępnych, najczęściej mają organizowane nauczanie indywidualne $(88 \%)$, często w domu ucznia, bez codziennych kontaktów z rówieśnikami ${ }^{37}$. Nie jest to efektywny sposób zaspokojenia specjalnych potrzeb edukacyjnych tej grupy uczniów. Pewną nadzieję na zmianę tego stanu można wiązać z obowiązującymi od pewnego czasu przepisami finansowymi zwiększającymi wysokość subwencji oświatowej dla jednostek samorządu terytorialnego (JST) na realizację obowiązku szkolnego tej grupy uczniów i wprowadzonych od stycznia 2016 r. uregulowaniach wymuszających na samorządach zatrudnianie dodatkowej osoby realizującej wspólnie z nauczycielem zadania edukacyjne i terapeutyczne, w klasach do których uczęszcza uczeń z autyzmem, zespołem Aspergera lub niepełnosprawnością sprzężoną. Niestety nadal brakuje systemowych

36 Por. Bowlby, Ainsworth za: E. Pisula, Autyzm i przywiazanie. Studia nad interakcjami dzieci $z$ autyzmem $i$ ich matek, Gdańskie Wydawnictwo Psychologiczne, Gdańsk 2003.

37 A. Deja, Tekst powstał dla Porozumienia AUTISM-EUROPE, w ramach prowadzanych badań nad systemem oświaty dla osób z autyzmem w krajach członkowskich UE. Fundacja SYNAPSIS 2006 www.synapsis.org.pl/_synapsis_1/images /stories/poradnictwo/systeme.pdf [26.02.2015]. 
działań przygotowujących całą społeczność szkolną na przyjęcie tych "specjalnych" uczniów.

We Włoszech, kraju, w którym od 40 lat realizowana jest edukacja włączająca, wypracowano efektywne sposoby włączania dzieci ze SPE do grupy rówieśniczej. Jednym z nich jest model postępowania realizowany $w$ rejonie Veneto. Jest to etapowy proces wprowadzenia dziecka z autyzmem do szkoły i zespołu klasowego ${ }^{38}$. $\mathrm{W}$ procesie uczestniczy cała społeczność szkolna. Realizowany jest przy udziale specjalistów, którzy wspólnie z pracownikami, rodzicami i uczniami planują, realizują, monitorują i oceniają przebieg tych działań. Towarzyszą nauczycielom aż do momentu, kiedy wspólnie ustalą, że społeczność szkolna jest gotowa samodzielnie realizować zadania służące realizacji specjalnych potrzeb edukacyjnych ucznia ${ }^{39}$. Interesująca propozycją opracowaną na terenie naszego kraju jest pięcioetapowy model włączania dziecka $\mathrm{z}$ autyzmem lub zespołem Aspergera do grupy rówieśniczej i tworzenia warunków sprzyjających uczeniu się autorstwa A. Florek i K. Hamerlak z fundacji Czas dzieciństwa ${ }^{40}$.

Niepełnosprawność $\mathrm{w}$ różnym stopniu wpływa na realizację zadań rozwojowych średniego i późnego dzieciństwa. Możliwe są ograniczenia i opóźnienia rozwoju, widoczne w zakresie kompetencji ruchowych, poznawczych, komunikowania się, rozwoju mowy i języka, kompetencji społecznych, emocjonalnych i osobowościowych ${ }^{41}$.

${ }^{38}$ Opis na podstawie prezentacji przygotowanej przez nauczyciela klas początkowych A. Montalbano z Instituto Comprena na temat integracji dziecka z autyzmem z kolegami z klasy (prezentacja filmów ukazujących metody pracy przygotowujące dzieci do spotkania z uczniem niepełnosprawnym). Spotkanie odbyło się w ramach wyjazdu studyjnego do Włoch zorganizowanego przez Unię Europejskich Federalistów we wrześniu 2012 r.

${ }^{39}$ K. Bidziński, Rola szkoły w kształceniu..., s. 143-164.

${ }^{40}$ A. Florek, K. Hamerlak, Dziecko autystyczne i z zespotem Aspergera w przedszkolu i szkole. Wtaczanie do grupy rówieśniczej i tworzenie warunków sprzyjających uczeniu się, Bank dobrych praktyk ORE Warszawa http://www.czasdziecinstwa.com.pl/ wlaczanie-do-grupy-rowiesniczej-dzieci-z- zespolem-aspergera/ [20.03.2015].

${ }^{41}$ B. Witkowska, Dziecko z niepetnosprawnościa wobec zadań rozwojowych średniego dzieciństwa, [w:] Dziecko ze specjalnymi potrzebami edukacyjnymi w..., s. 314-334; 
Nasilenie trudności w realizacji zadań rozwojowych może być bardzo różne, czasem sytuacja rozwojowa wymaga tylko niewielkiego wsparcia, innym razem pojawia się konieczność daleko idącej indywidualizacji działań edukacyjnych oraz objęcia dziecka specjalistyczną pomocą. W sytuacji, gdy zaburzenia rozwoju stwarzają zagrożenie wystąpienia niepełnej sprawności lub wywołały niepełnosprawność, na wniosek rodziców dzieci mogą otrzymać orzeczenie o potrzebie kształcenia specjalnego. Uczniowie ci poprzez uzyskany status prawny stają się specjalnymi odbiorcami usług edukacyjnych. Zwykle są to działania polegające na zaspokojeniu indywidualnych potrzeb edukacyjnych w ramach kształcenia specjalnego realizowanego na terenie szkoły, otoczeniu dziecka pomocą psychologiczno-pedagogiczną lub działaniami o charakterze terapeutycznym $\mathrm{w}$ ramach zajęć rewalidacyjnych. Podjęcie tego typu działań musi być poprzedzone prawidłowo przeprowadzoną diagnozą stanu dziecka i trafnym określeniem zakresu jego indywidualnych potrzeb rozwojowych i edukacyjnych. Posiadane przez uczniów orzeczenie o potrzebie kształcenia specjalnego pozwala z jednej strony na daleko idącą indywidualizację kierowanych do nich działań edukacyjno-terapeutycznych, z drugiej może ukazywać ich jako uczniów o niskich kompetencjach, wymagających odrębnego, specjalistycznego traktowania. Dla kształtujących się podstaw tożsamości szczególnie niekorzystny wpływ ma stawianie wobec dziecka nieadekwatnych zadań, okazywanie dezaprobaty i zniecierpliwienia podczas doświadczanych trudności. Także zbyt silna koncentracja na dziecięcych ograniczeniach i słabościach, nadmiar działań korygujących i naprawczych, bezpośrednie etykietowanie może być dla dziecka sygnałem braku akceptacji otoczenia dla jego inności i źródłem licznych frustracji. Teoria samospełniających się oczekiwań trafnie ilustruje mechanizm i potencjalne konsekwencje tego typu doświadczeń dla ucznia ${ }^{42}$.

P. Kurtek, Dziecko z niepetnosprawnościa wobec zadań rozwojowych późnego dzieciństwa, [w:] Dziecko ze specjalnymi potrzebami edukacyjnymi w..., s. 391-406.

42 C. Braun, Oczekiwania nauczyciela: dynamika spoteczno-psychologiczna, [w:] Efekty oczekiwań interpersonalnych, red. S. Trusz, Wydawnictwo Naukowe Scholar, Warszawa 2013, s. 311-333. 
A. Sokołowska-Kasperiuk zwróciła uwagę na niepokojący problem tak zwanych quasi-zaburzeń (lub pozornych zaburzeń rozwoju). Wspólnie ze swoimi współpracownikami prowadzącymi działania diagnostyczno-terapeutyczne w Pracowni Badań nad Autyzmem zaobserwowała grupę dzieci, których stan funkcjonowania zdaniem ich opiekunów nosił znamiona poważnego zaburzenia rozwoju. Jednak pogłębiona diagnoza ukazała zupełnie inne podłoże zachowań tych dzieci. Okazało się, że symptomy nieprawidłowego zachowania uwarunkowane są środowiskowo i mają charakter objawowy. Pełnią funkcję adaptacyjną do trudnej sytuacji, $\mathrm{w}$ jakiej dziecko się znajduje przez dłuższy czas, nie mając możliwości zmienienia jej, a która stoi w sprzeczności do jego potrzeb rozwojowych ${ }^{43}$.

Dla dorosłych z otoczenia tych dzieci, ich rodziców, nauczycieli łatwiej było wytłumaczyć zachowania dziecka wyimaginowanymi problemami natury biologicznej niż poszukać w swoim działaniu prawdziwych przyczyn tych trudnych zachowań. Odkrycie prawdziwego źródła problemu połączone $\mathrm{z}$ eliminacją ze środowiska dziecka czynników patologicznych oraz podjęcie działań terapeutycznych spowodowało cofnięcie się niepokojących zachowan. Autorka apeluje do nauczycieli i rodziców o rozwagę w prowadzeniu działań diagnostycznych, zachowanie daleko idącej uważności w wyjaśnianiu przyczyn trudnych zachowań. Przestrzega przed przypisywaniem dzieciom „etykiet”, która może towarzyszyć im przez wiele kolejnych lat, wyznaczając niekorzystną pozycję spoleczną oraz hamując rozwój.

Uczniowie z niepełnosprawnością mogą doświadczać poczucia niestosowności i niższości, jeśli w codziennych sytuacjach edukacyjnych nie uwzględnia się ich specjalnych potrzeb edukacyjnych. Pojawia się istotne pytanie, na ile szkoła ogólnodostępna może stać się miejscem przyjaznym i zapewniającym efektywną edukację dla tej szczególnej grupy uczniów?

${ }^{43}$ A. Sokołowska-Kasperiuk, Ku przemianom świadomości nauczycielskiej - o quasi-zaburzeniach rozwoju u dzieci, „Niepełnosprawność. Dyskursy pedagogiki specjalnej" 2013, nr 12, s. 83-100. 
Z perspektywy realizacji idei edukacji włączającej interesujące są wyniki badań, wskazujące, że praktyki socjalizacyjne realizowane $w$ klasach początkowych szkoły ogólnodostępnej niosą wiele zagrożeń dla kształtowania się tożsamości wszystkich uczniów ${ }^{44}$. Można przypuszczać, że zagrożenia te dotykać będą także uczniów niepełnosprawnych.

Marzenna Nowicka, dzięki zastosowaniu analiz etnometodologicznych, dokonała pogłębionej rekonstrukcji praktyk socjalizacyjnych wytwarzanych w sytuacjach komunikowania się na lekcjach w klasach początkowych. Aby wzbogacić obraz analizowanych procesów, autorka sięgnęła po dodatkowe procedury badawcze: fenomenografię do analizy konstruktów świadomości nauczycieli uczestniczących $\mathrm{w}$ procesie socjalizacji oraz badania semiotyczne $\mathrm{w}$ celu opisania socjalizacyjnej wartości znaków obecnych w przestrzeni klasy szkolnej. Nie ma tu niestety miejsca na pełną prezentację wszystkich wzorców działań socjalizacyjnych zrekonstruowanych na podstawie badań, zainteresowanych odsyłam do książki autorki ${ }^{45}$. $\mathrm{W}$ tym miejscu warto jedynie ukazać wynikające $\mathrm{z}$ tych analiz wnioski.

W badanych szkołach zdecydowanie dominowały praktyki określane, przez autorkę jako „socjalizacja stabilizująca”. Nauczyciele poprzez sterującą interwencję i gratyfikację pożądanych zachowań korygowali zachowania uczniów tak, aby były one jak najbardziej zgodne $\mathrm{z}$ obowiązującym w szkole wzorcem. W praktyce badanych szkół nie było miejsca na indywidualność i oryginalność uczniowskich zachowań, ceniono je za okazywane posłuszeństwo, całkowite podporządkowanie się dorosłym i obowiązującym w szkole zasadom.

Najczęściej podczas obserwowanych lekcji spotykany był styl działania nauczycieli oparty na dyrektywności i braku zaufania do kompetencji uczniów. Działania socjalizacyjne tego typu polegały na drobiazgowym instruowaniu uczniów, narzucaniu im sposobów

${ }^{44}$ M. Nowicka, Dziecko w procesie socjalizacji szkolnej - ku integracji czy dysonansowi, [w:] (Anty)edukacja wczesnoszkolna..., s. 178-203; M. Nowicka, Socjalizacja na lekcjach w klasach poczatkowych. Praktyki - Przestrzenie - Konceptualizacje, Wydawnictwo Adam Marszałek, Torun 2010.

${ }^{45} \mathrm{M}$. Nowicka, Socjalizacja na lekcjach w klasach początkowych... 
myślenia i percepcji rzeczywistości, stałym dyscyplinowaniu, dystansowaniu się nauczycieli od uczniów, nadmiernym podkreślaniu dominującej roli nauczyciela, ale też maskowaniem i wzmacnianiem władzy klimatem życzliwości, silnym uzależnianiem dziecka od autorytetu nauczyciela, ograniczaniem jego samodzielności ${ }^{46}$. Pojawiają się uzasadnione obawy, że tak zorganizowana przestrzeń socjalizacji nie może stanowić korzystnego rozwojowo miejsca dla uczniów z niepełnosprawnością.

Zwolennicy teorii interakcji społecznych zwracają uwagę, że kształtowanie tożsamości dokonuje się za pośrednictwem interakcji z innymi ludźmi i przy ich znaczącym wsparciu. Szczególna rola w tym procesie przypada społecznej komunikacji, za pomocą której dochodzi do kontaktów i interakcji jednostki ze światem. Dlatego tak ważną kompetencją nauczyciela jest umiejętność wspierania uczniów w nawiązywaniu i podtrzymywaniu interakcji rówieśniczych. Socjalizacyjną wartość mają zarówno interakcje powstające w sytuacjach formalnych podczas realizowanego toku lekcji, jak i w sytuacjach nieformalnych podczas przerw, zajęć pozalekcyjnych. Szczególnie sytuacje dydaktyczne mogą stanowić dogodną do tego przestrzeń, ponieważ ich przebieg jest w dużym stopniu zależny od decyzji nauczycieli. Uczeń, w tym szczególnie uczeń z niepełnosprawnością, ma większe szanse na rozwój kompetencji społecznych, jeśli nauczyciele stosują w swojej praktyce dydaktycznej komunikację partycypacyjną, doceniają wartość dydaktycznego dyskursu, zapraszają uczniów do dzielenia się informacjami o faktach, wyrażania własnych opinii, przekonań, sądów; stawiania pytań i odpowiadania na nie, podejmowania dyskusji. Nie wystarczy jednak stworzyć uczniom przestrzeń do edukacyjnego dialogu, ważne jest takie zorganizowanie tych sytuacji dydaktycznych, aby także uczniowie o niższych kompetencjach społecznych mieli udział w tworzonym dyskursie. Pewną formą efektywnego działania jest stosowanie przez nauczycieli nauczania kooperatywnego, którego istota polega na zorganizowaniu pracy uczniów w taki sposób, aby

46 Ibidem, s. 163-212. 
była konieczność współdziałania wszystkich realizatorów działania ${ }^{47}$.

Jak wynika z ogólnopolskich badań 2006-2011 dotyczących analizy szkolnego kontekstu umiejętności trzecioklasistów opisanych przez M. Żytko48, nauczyciele edukacji wczesnoszkolnej zawłaszczają przestrzeń komunikacyjną klasy szkolnej. Autorka pisze o klasie jako "teatrze jednego autora", w którym to nauczyciel poprzez bardzo częste stosowanie strategii nauczania frontalnego uniemożliwia uczniom wymianę opinii, spostrzeżeń, stawiania pytań, odpowiadania na pytania, argumentowania ${ }^{49}$.

W opisanej praktyce edukacji wczesnoszkolnej dostrzega się: przewagę dyrektywnego (instrukcyjnego) sposobu komunikowania się nauczyciela z uczniami; koncentrację nauczycieli na formalnych aspektach posługiwania się przez dzieci językiem (ważniejsze staje się to, jak, a nie co dziecko mówi); brak zachęcania dzieci do dyskusji i wymiany myśli, narzucanie sądów czy opinii przez nauczycieli.

Badani nauczyciele najczęściej podejmowali aktywność w postaci: wydawania poleceń, zadawania pytań sprawdzających uczniowską wiedzę, podpowiadania i odpowiadania za ucznia. Zdecydowanie rzadziej nauczyciele komunikowali $\mathrm{w}$ celu wspierania uczniów poprzez ukierunkowanie ich pracy, akceptowali propozycje i pomysły uczniów, formułowali pytania otwarte, zachęcali uczniów do prezentowania własnego stanowiska, słuchali wypowiedzi uczniów ${ }^{50}$.

${ }^{47}$ M. Bidzińska, K. Bidziński, Uczenie się i nauczanie kooperatywne na przykładzie lekcji biologii, „Poradnik nauczyciela” 2002, nr 9.

${ }^{48}$ M. Żytko, Edukacja jezzykowa w szkole - między dążeniem do formalizacji schematu a refleksja nad uczestnictwem w zdarzeniach komunikacyjnych, [w:] (Anty)edukacja wczesnoszkolna..., s. 315-344.

${ }^{49}$ M. Dąbrowski, Edukacyjna codzienność klasy trzeciej, [w:] Nauczyciel ksztatcenia zintegrowanego 2008 - wiele różnych światów, red. M. Dagiel, M. Żytko, Centralna Komisja Egzaminacyjna, Warszawa 2009, s. 127; M. Dąbrowski, Edukacyjność codzienna szkoły wiejskiej, [w:] Szkolne rzeczywistości klas trzecich w środowisku wiejskim, Centralna Komisja Egzaminacyjna, Warszawa 2010, s. 116.

${ }_{50}$ M. Dąbrowski, Edukacyjna codzienność klasy trzeciej, [w:] Nauczyciel ksztatcenia zintegrowanego 2008..., s. 127; M. Dąbrowski, Edukacyjność codzienna szkoty wiejskiej, [w:] Szkolne rzeczywistości klas trzecich w środowisku wiejskim..., s. 116. 
Podobnie niekorzystnie przedstawia się analiza podejmowanych przez uczniów czynności. Podczas obserwowanych zajęć dydaktycznych dominowało: słuchanie wypowiedzi nauczycieli, sprawdzanie uczniowskiej wiedzy oraz czynności organizacyjne. Zdecydowanie mniej czasu uczniowie poświęcali na gry i zabawy dydaktyczne, aktywność twórczą i badawczą; prowadzenie dyskusji. W tak zorganizowanej przestrzeni komunikacyjnej źle funkcjonują wszyscy uczniowie, ale szczególnie uczniowie $\mathrm{z}$ niepełnosprawnością, którzy nie mogą realizować swoich potrzeb. Używając metafory zaproponowanej przez M. Żytko, uczniowie ci w teatrze szkolnym odgrywają rolę aktorów drugiego planu, a może tylko statystów. Potwierdzają te przypuszczenia liczne badania socjometryczne i analizy uczniowskich relacji $w$ klasach integracyjnych i ogólnodostępnych prowadzone przez pedagogów specjalnych ${ }^{51}$.

W procesie socjalizacji uczniów doświadczających ograniczonej sprawności organizowanym w przestrzeni edukacyjnej szczególnego znaczenia nabiera sposób komunikowania przez nauczyciela o niepełnosprawności jako ludzkim fenomenie.

Analizy opracowane przez D. Krzemińską i K.D. Rzedzicką w oparciu o badania J. Wyczesany i E. Dyduch (1996) oraz H. Łaś (2002) potwierdzają tezę, że wielu nauczycieli cechuje brak znajomości podstawowych pojęć z zakresu pedagogiki specjalnej. W relacji z uczniami niepełnosprawnymi dominuje "powierzchowne i intuicyjne podejście i zbytnia koncentracja na upośledzeniu i brakach" połączona z przeświadczeniem o zubożeniu potrzeb dziecka

51 A Jagier, M. Kosowska, Rola nauczyciela w budowaniu relacji społecznych, [w:] Relacje dziecka z wada stuchu w szkole, red. A. Jagier, M. Kosowska, Wydawnictwo Difin, Warszawa 2011, s. 96; I. Chrzanowska, Problemy edukacji dzieci i młodzieży $z$ niepetnosprawnością. Regionalna specyfika czy ogólnopolska tendencja, Oficyna Wydawnicza "Impuls”, Kraków 2010; M. Chodkowska, Razem damy sobie radę! W drodze do zintegrowanego społeczeństwa, WSiP, Warszawa, 2009; M. Rozenbajgier, Dziecko niepetnosprawne w grupie rówieśniczej, [w:] O poznawaniu siebie $i$ świata przez..., s. 457-472; J. Sikorski, Pozycja społeczna dziecka niepetnosprawnego w klasie integracyjnej [w:] O poznawaniu siebie i świata..., s. 491-496; A. Maciarz, Integracja spoteczna dzieci niepetnosprawnych, WSiP, Warszawa 1987. 
niepetnosprawnego, co przekłada się na brak inwencji w podejmowanych działaniach oraz ambiwalencje w ocenianiu ucznia, z zastosowaniem nadmiernych wymagań bądź taryfy ulgowej52.

Mimo upływu wielu lat od teoretycznego przewrotu w myśleniu o niepełnosprawności, w świadomości społecznej, w tym także poglądach nauczycieli, ciągle obecny jest medyczny model tego zjawiska.

Podejście to było/jest wyznaczane przez myślenie o niepełnosprawności w kontekście medykalizacji indywidualnego deficytu, braku, jako pochodnej funkcjonalnych ograniczeń czy psychologicznych strat (medyczny/indywidualny model niepełnosprawności). Tak ujęta niepełnosprawność wymaga działań naprawczych w formie rehabilitacji ufundowanej na „ideologii normalności”, wzmaga potrzebę upodabniania, dorównywania odmienności do normy ${ }^{53}$.

Przyjęcie przez nauczycieli tego modelu może mieć zgubny wpływ na wspólnie tworzony z uczniami dyskurs niepełnosprawności i negatywnie wpływać na kształtowanie się ich tożsamości. Prowadzi do nadmiernej koncentracji na inności rozwojowej dziecka i zbyt mocnego akcentowania jego problemów, myślenia o niepełnosprawności głównie jako „tragedii osobistej” oraz przekonania o konieczności uruchomienia działań naprawczych prowadzących do korygowania dziecięcej „niedoskonałości”, zawłaszczenie zabiegami terapeutycznymi niemal całej przestrzeni dziecięcego świata ${ }^{54}$.

Interesujące badania oparte na analizie procesu edukacyjnego w wymiarze nauczycielskiego i uczniowskiego komunikowania o zjawisku niepełnosprawności oraz językowych znaczeń przekazów tekstów szkolnych przeprowadziła S. Sadowska. Analiza form i semantyki wypowiedzi badanych daje możliwość identyfikowania wyrażonych w języku reprezentacji umysłowych o osobach z nie-

52 D. Krzemińska, K.D. Rzedzicka, O przygotowaniu zawodowym pedagogów specjalnych - krajobraz (bez) zmian?, „Niepełnosprawność” 2009, nr 1, s. 113-124.

53 Ibidem, s. 118.

54 Pisałem o tym w złożonym do druku artykule pt. Kompetencje komunikacyjne nauczycieli szkół ogólnodostępnych podstawa realizacji idei edukacji włączajacej. 
pełnosprawnością55. W celu zebrania danych językowych autorka zastosowała metodę swobodnych skojarzeń, która pozwala na dokonanie wglądu w subtelny, mniej kontrolowany proces stereotypizacji. Z badań tych wynika, że myślenie nauczycieli cechuje wyraźny podział na uczniów pełnosprawnych i niepełnosprawnych. W wypowiedziach nauczycieli pojawia się portret osoby niepełnosprawna jako „bezradnej”, ,zależnej od innych osób”, "zdanej całkowicie na pomoc osób trzecich". Podobnie mało racjonalny obraz osoby z niepełnosprawnością wyłania z analizy uczniowskich skojarzeń. Nauczyciele, opisując swoje działania związane z edukacją uczniów niepełnosprawnych, koncentrują się na czynnościach opieki, pomocy, wsparciu, przejawianiu szczególnej troski, bardzo rzadko wskazują możliwości normalnej współpracy, czy traktowania ucznia z niepełnosprawnością jak każdego innego.

Także dokonana przez autorkę analiza komunikatów językowych zawartych w tekstach edukacyjnych stosowanych $\mathrm{w}$ badanych szkołach nie jest zbyt optymistyczna. Nie wszystkie tworzące szkolny dyskurs teksty pozwalają na zastosowanie ich do redefiniowania pojęcia „osoba z niepełnosprawnością” oraz budowania moralno-powinnościowego obrazu świata relacji z tymi osobami. Podobnie krytycznej oceny tekstów literackich stosowanych przez nauczycieli I etapu w „edukacji do Innego” dokonała M. Nowicka. Wybierane przez uczestniczących w badaniach nauczycieli teksty, służące wprowadzaniu uczniów w świat społeczny, cechowały się: natrętnym moralizatorstwem, schematycznością budowy tekstu i modeli zachowań; małym zróżnicowaniem prezentowanych odmienności; powielaniem stereotypowych sądów i uprzedzeńn ${ }^{56}$.

Od nauczycieli pracujących w klasach ogólnodostępnych, do których przyjmowani są uczniowie niepełnosprawni, oczekuje się, że będą umieli stworzyć odpowiednie warunki socjalizacji wszyst-

55 S. Sadowska, Ku edukacji zorientowanej na zmiane społecznego obrazu osób niepetnosprawnych, Wydawnictwo Edukacyjne „Akapit”, Torun 2005, s. 115.

56 M. Nowicka, Praca z tekstem literackim - szansa czy przeszkoda w edukacji do Innego, [w:] Światy dziecięcych znaczeń, red. D. Klus-Stańska, Wydawnictwo Akademickie "Żak", Warszawa 2004, s. 47 i n. 
kim swoim podopiecznym. Podstawą tych działań jest troska o właściwe relacje społeczne w zespole uczniowskim i całej społeczności szkolnej. Nauczyciele poprzez właściwe nastawienie wobec uczniów z niepełnosprawnością mogą modelować i wspierać właściwe interakcje między uczniami oraz przełamywać stereotypy i uprzedzenia. Wskazywane przez S. Sadowską ${ }^{57}$ możliwe do zastosowania w edukacji metody tego typu działań, to: interwencja w jakość kontaktów między pełnosprawnymi i niepełnosprawnymi; wzbogacanie wiedzy na temat przedstawicieli obcej grupy; wytworzenie wspólnej tożsamości grupowej; rozwijanie empatii i odgrywanie ról; wpływ normatywny polegający na zwiększaniu wyrazistości norm społecznych przeciwnych uprzedzeniom. Szczególnie skutecznym sposobem wydaje się budowanie wspólnoty MY - ukazywanie podobieństw między uczniami, przy jednoczesnym ukazywaniu wartości wynikającej z różnorodności ludzkich doświadczeń i postaw.

\section{Podsumowanie}

Jarome S. Bruner ${ }^{58}$ w zbiorze esejów na temat związku między edukacją a kulturą prowadzi interesujące, nie tylko z perspektywy pedagoga, rozważania dotyczące roli szkoły w rozwiązaniu dylematów człowieka, osłabieniu zagrożeń i rozwiązywaniu problemów, z jakimi przychodzi mierzyć się współczesnym społeczeństwom. Nadzieję budzi opracowanie i wdrożenie nowej, kooperatywnej kultury edukacyjnej szkoły, w której wszystkie podmioty skoncentrowane są na wspólnym rozwiązywaniu problemów i uruchomieniu procesu wzajemnego nauczania. Te wspólne działania stanowią nie tylko dogodną przestrzeń uczenia się, ale również ośrodek kształtowania własnej tożsamości „służą rozbudzaniu świadomości

57 S. Sadowska, op. cit., s. 125-135.

58 J. Bruner, Kultura edukacji, Towarzystwo Autorów i Wydawców Prac Naukowych Univeristas, Kraków 2006. 
i metapoznania swoich uczestników oraz podnoszenia ich samooceny”. W szkole tej ważne miejsce zajmują „,zagadnienia tożsamości kulturowych, odrębności zróżnicowanych grup etnicznych oraz niższych warstw społecznych". Równoprawne, partnerskie, świadome współdziałanie przedstawicieli odrębnych grup mniejszościowych (klasowych, etnicznych, religijnych, narodowych,) pozwala na równoważenie grupowych tożsamości i budowanie poczucia przynależności do wspólnej szerszej niż lokalna społeczności. Szkoły takie mogą stać modelem - „kontrkulturą" ukazującą poprzez codzienne doświadczenia, jak może lepiej funkcjonować całe społeczeństwo, w którym jest miejsce dla każdego bez względu na wrodzony potencjał czy zasoby społeczno-kulturowe jego najbliższego otoczenia.

Idea tworzenia kultur szkolnych, funkcjonujących w oparciu o wzajemność wspólnoty uczących się podmiotów, ogłoszona przez J.S. Brunera prawie 20 lat temu jest ciągle aktualną i atrakcyjną propozycją. Dzisiaj w obliczu różnych dramatycznych społecznych doświadczeń nabiera szczególnego znaczenia. Jest to wyzwanie, które zapisano także w programie Światowej Deklaracji Edukacja dla Wszystkich zainicjowanym w 1990 r. przez UNESCO i od tego czasu realizowanym w różnych częściach globu ${ }^{59}$. Najważniejszym celem tego programu jest doprowadzenie do zaspokojenia podstawowych potrzeb edukacyjnych wszystkich ludzi, uwzględniając jednocześnie wysoką jakość procesu kształcenia. Podobne myśli można dostrzec w realizowanej od lat dziewięćdziesiątych idei edukacji włączającej. W sprawozdaniu z Międzynarodowej Konferencji na temat edukacji włączającej z 2008 r. stwierdza się, że:

Idea edukacji włączającej wypływa z szeregu pojęć oraz wartości dotyczących określonego typu społeczeństwa, które należy zbudować, a także ideału ludzkiej osoby, który należy rozwijać. Jeśli chcemy, by nasze społeczeństwo było otwarte, bardziej nastawione na pokojowe współżycie oraz miało szacunek do odmienności,

${ }^{59}$ Edukacja dla Wszystkich (Education for All) - opis programu http:/ / www. unesco.pl/edukacja/edukacja-dla-wszystkich/ [25.09.2015]. 
trzeba zapewnić uczniom wzorce tych wartości - i możliwość ich naśladowania - w ramach procesu kształcenia odbywającego się w szkole i poza nią 60 .

Będzie to możliwe wtedy, kiedy uda nam się uczynić ze szkoły ogólnodostępnej wspólnotę równoprawnych, uczących się podmiotów. Wtedy też stanie się ona bezpiecznym miejscem kształtowania podstaw tożsamości wszystkich uczniów, także tych, których specjalne potrzeby edukacyjne wynikają z niepełnosprawności.

\section{Bibliografia}

Bidzińska M., Bidziński K., Uczenie się i nauczanie kooperatywne na przykładzie lekcji biologii, „Poradnik nauczyciela” 2002, nr 9.

Bidziński K., Rodzina jako prymarny kontekst rozwojowy jednostki, [w:] Dziecko ze specjalnymi potrzebami edukacyjnymi w drodze ku dorostości, red. W. Pilecka, M. Rutkowski, Oficyna Wydawnicza „Impuls”, Kraków 2009.

Bidziński K., Rola szkoły w kształceniu aksjologicznym dzieci w młodszym wieku szkolnym, [w:] Doświadczanie poznawania świata przez dzieci w młodszym wieku szkolnym, red. I. Adamek, B. Pawlak, Wydawnictwo Libro, Kraków 2012.

Bieleń B., Rówieśnik - partner w rozwoju, [w:] Pedagogika małego dziecka wybrane zagadnienia, red. M. Karwowska-Struczyk, E. Słodownik-Rycaj, Instytut Badań Edukacyjnych, Warszawa 2007.

Blumer H., Społeczeństwo jako symboliczna interakcja, [w:] Kryzys i schizma. Antyscjentyczne tendencje w socjologii współczesnej, red. E. Mokrzycki, PIW, Warszawa 1984.

Błeszyńska K., Niepetnosprawność a struktura identyfikacji społecznych, Wydawnictwo Akademickie "Żak”, Warszawa 2001.

Bokszański Z., Tożsamości zbiorowe, Wydawnictwo PWN, Warszawa 2008.

Bourdieu P., Passeron J.C., Reprodukcja. Elementy teorii systemu nauczania, Wydawnictwo Naukowe PWN, Warszawa 2006.

Braun C., Oczekiwania nauczyciela: dynamika społeczno-psychologiczna, [w:] Efekty oczekiwań interpersonalnych, red. S. Trusz, Wydawnictwo Naukowe Scholar, Warszawa 2013.

60 Profil nauczyciela edukacji włączającej, Europejska Agencja Rozwoju Edukacji Uczniów ze Specjalnymi Potrzebami, Odense, Dania, 2012, s. 28. https://www. european-agency.org/sites/default/files/te4i-profile-of-inclusive-teachers_Profileof-Inclusive-Teachers-PL.pdf [22.03.2015]. 
Bruner J., Kultura edukacji, Towarzystwo Autorów i Wydawców Prac Naukowych Univeristas, Kraków 2006.

Chodkowska M., Razem damy sobie radę! W drodze do zintegrowanego społeczeństwa, WSiP, Warszawa 2009.

Chrzanowska I., Problemy edukacji dzieci i młodzieży z niepetnosprawnościa. Regionalna specyfika czy ogólnopolska tendencja, Oficyna Wydawnicza „Impuls”, Kraków 2010.

Cytowska B., Trudne drogi adaptacji. Watki emancypacyjne w analizie sytuacji dorostych osób z niepetnosprawnościa intelektualna we współczesnym społeczeństwie polskim, Oficyna Wydawnicza „Impuls”, Kraków 2013.

Czerepaniak-Walczak M., Pedagogika emancypacyjna, rozwój świadomości krytycznej człowieka, Gdańskie Wydawnictwo Psychologiczne, Gdańsk 2006.

Dąbrowski M., Edukacyjna codzienność klasy trzeciej, [w:] Nauczyciel kształcenia zintegrowanego 2008 - wiele różnych światów, red. M. Dagiel, M. Żytko, Centralna Komisja Egzaminacyjna, Warszawa 2009.

Dąbrowski M., Edukacyjność codzienna szkoty wiejskiej, [w:] Szkolne rzeczywistości klas trzecich w środowisku wiejskim, Centralna Komisja Egzaminacyjna Warszawa 2010 .

Erikson E.H., Dzieciństwo i społeczeństwo, przeł. P. Hejmej, Wydawnictwo Rebis, Poznań 2000.

Grochowalska M., Codzienność świata społecznego szkoły kontekstem doświadczania napięć przez nauczycieli edukacji wczesnoszkolnej, [w:] Szkoła jako przestrzeń edukacyjnego (nie)porozumienia, red. A. Domagała-Kręcioch i B. Majerek, Oficyna Wydawnicza „Impuls”, Kraków 2014.

Jagier A., Kosowska M., Rola nauczyciela w budowaniu relacji spotecznych, [w:] Relacje dziecka z wada stuchu w szkole, red. A. Jagier, M. Kosowska, Wydawnictwo Difin, Warszawa 2011.

Jawłowska A., Tożsamość na sprzedaż, [w:] Wokót problemów tożsamości, red. A. Jawłowska, Wydawnictwo LTW, Warszawa 2001.

Kirenko J., Niektóre uwarunkowania psychospołecznego funkcjonowania osób z uszkodzeniem rdzenia kręgowego, Wydawnictwo UMCS, Lublin 1995.

Klus-Stańska D., Wprowadzenie do ksiażki, [w:] (Anty)edukacja wczesnoszkolna, red. D. Klus-Stańska, Oficyna Wydawnicza „Impuls”, Kraków 2014.

Kopeć D., Odkrywanie siebie przez osobę z głęboka niepetnosprawnością w kontekście teorii wczesnego rozwoju poczucia siebie Daniela Sterna, [w:] O poznawaniu siebie i świata przez dziecko ze specjalnymi potrzebami edukacyjnymi, red. W. Pilecka, K. Bidziński, M. Pietrzkiewicz, Wydawnictwo Uniwersytetu Humanistyczno-Przyrodniczego Jana Kochanowskiego, Kielce 2008.

Kopeć D., Rzeczywistość (nie)edukacyjna osoby z głęboka niepetnosprawnościa intelektualna. Zbiorowe instrumentalne studium przypadku, Wydawnictwo Naukowe UAM, Poznań 2013. 
Kościelska M., Oblicza upośledzenia, PWN, Warszawa 1995.

Krause A., Teoretyczne inspiracje pedagogiki specjalnej - pedagogika emancypacyjna, „Studia Edukacyjne” 2013, nr 28.

Krause A., Współczesne paradygmaty pedagogiki specjalnej, Oficyna Wydawnicza „Impuls", Kraków 2010.

Krzemińska D., Rzedzicka K. D., O przygotowaniu zawodowym pedagogów specjalnych - krajobraz (bez) zmian?, „Niepełnosprawność” 2009, nr 1.

Kurtek P., Dziecko z niepetnosprawnościa wobec zadań rozwojowych późnego dzieciństwa, [w:] Dziecko ze specjalnymi potrzebami edukacyjnymi w drodze ku dorostości, red. W. Pilecka, M. Rutkowski, Oficyna Wydawnicza „Impuls”, Kraków 2009.

Maciarz A., Integracja społeczna dzieci niepetnosprawnych, WSiP, Warszawa 1987.

Nowicka M., Dziecko w procesie socjalizacji szkolnej - ku integracji czy dysonansowi, [w:] (Anty)edukacja wczesnoszkolna, red. D. Klus-Stańska, Oficyna Wydawnicza „Impuls". Kraków 2004.

Nowicka M., Praca z tekstem literackim - szansa czy przeszkoda w edukacji do Innego, [w:] Światy dziecięcych znaczeń, red. D. Klus-Stańska, Wydawnictwo Akademickie „Żak”, Warszawa 2004.

Nowicka M., Socjalizacja na lekcjach w klasach początkowych. Praktyki - Przestrzenie Konceptualizacje, Wydawnictwo Adam Marszałek, Torun 2010.

Pisula E., Autyzm i przywiązanie. Studia nad interakcjami dzieci z autyzmem i ich matek, Gdańskie Wydawnictwo Psychologiczne, Gdańsk 2003.

Rozenbajgier M., Dziecko niepetnosprawne w grupie rówieśniczej, [w:] O poznawaniu siebie i świata przez dziecko ze specjalnymi potrzebami edukacyjnymi, red. W. Pilecka, K. Bidziński, M. Pietrzkiewicz, Wydawnictwo Uniwersytetu Humanistyczno-Przyrodniczego Jana Kochanowskiego, Kielce 2008.

Rzeźnicka-Krupa J., Niepetnosprawność i świat społeczny. Szkice metodologiczne, Oficyna Wydawnicza „Impuls”, Kraków 2009.

Rzeźnicka-Krupa J., Tożsamość i wykluczenie. Fenomen niepetnosprawności na marginesach ludzkiej egzystencji?, [w:] Obszary społecznej marginalizacji - niepetnosprawność, red. J. Rutkowiak i A. Krause, Wydawnictwo OSW, Olsztyn 2009.

Sadowska S., Ku edukacji zorientowanej na zmiane społecznego obrazu osób niepetnosprawnych, Wydawnictwo Edukacyjne „Akapit”, Torun 2005.

Sadowska S., Praktyka tworzenia edukacyjnej wspólnoty - o edukacyjnej codzienności w kontekście jawnych i ukrytych wzorów kultury szkolnej, "Studia Edukacyjne" 2015, nr 34.

Schútz A., O wielości światów. Szkice z socjologii fenomenologicznej, Wydawnictwo Naukowe Nomos, Kraków 2008.

Sikorski J., Pozycja społeczna dziecka niepetnosprawnego w klasie integracyjnej, [w:] O poznawaniu siebie i świata przez dziecko ze specjalnymi potrzebami edukacyjnymi, red. W. Pilecka, K. Bidziński, M. Pietrzkiewicz, Wydawnictwo Uniwersytetu Humanistyczno-Przyrodniczego Jana Kochanowskiego, Kielce 2008. 
Sokołowska-Kasperiuk A., Ku przemianom świadomości nauczycielskiej - o quasi-zaburzeniach rozwoju u dzieci, „Niepełnosprawność. Dyskursy pedagogiki specjalnej” 2013, nr 12.

Szczepska-Pustkowska M., Szkolna petryfikacja rodzacej się tożsamości dziecka, [w:] (Anty)edukacja wczesnoszkolna, red. D. Klus-Stańska, Oficyna Wydawnicza „Impuls" Kraków 2014.

Ustawa o systemie oświaty z dnia 7 września 1991 r. (Dz.U. z 1991 r. Nr 95, poz. 425).

Waloszek D., Między przedszkolem a szkoła. Rozważania o gotowości dzieci do podjęcia nauki w szkole, Wydawnictwo Akademickie Żak, Warszawa 2014.

Witkowska B., Dziecko z niepetnosprawnościa wobec zadań rozwojowych średniego dzieciństwa, [w:] Dziecko ze specjalnymi potrzebami edukacyjnymi w drodze ku dorostości, red. W. Pilecka, M. Rutkowski, Oficyna Wydawnicza „Impuls”, Kraków 2009.

Witkowski L., Tożsamość $i$ zmiana: epistemologia $i$ rozwojowe profile w edukacji, Wydawnictwo Naukowe Dolnośląskiej Szkoły Wyższej, Wrocław 2010.

Witkowski L., Rozwój i tożsamość w cyklu życia. Studium koncepcji Erika H. Eriksona, Wydawnictwo UMK, Torun 1989.

Żytko M., Edukacja językowa w szkole - między dążeniem do formalizacji schematu a refleksja nad uczestnictwem w zdarzeniach komunikacyjnych, [w:] (Anty)edukacja wczesnoszkolna, red. D. Klus-Stańska, Oficyna Wydawnicza „Impuls”, Kraków 2014.

\section{Źródła internetowe}

Deja A., Tekst dla Porozumienia AUTISM-EUROPE, w ramach prowadzanych badań nad systemem oświaty dla osób z autyzmem w krajach członkowskich UE. Fundacja SYNAPSIS 2006 www.synapsis.org.pl/_synapsis_1/images/sto ries/poradnictwo/systeme.pdf [26.02.2015].

Edukacja dla Wszystkich (Education for All) - opis programu http:/ / www.unesco. pl/edukacja/edukacja-dla-wszystkich/ [25.09.2015].

Florek A., Hamerlak K., Dziecko autystyczne $i$ zespołem Aspergera w przedszkolu i szkole. Wtaczanie do grupy rówieśniczej i tworzenie warunków sprzyjających uczeniu się, Bank dobrych praktyk ORE Warszawa http://www.czasdziecinstwa.com. pl/wlaczanie-do-grupy-rowiesniczej-dzieci-z-zespolem-aspergera/ [20.03.2015].

Kojder A., Co to jest teoria naznaczenia społecznego?, "Studia Socjologiczne” 1980, nr 3(78); www.ipsir.uw.edu.pl/.../AKojder4Co\%20to\%20jest\%20teoria\%20naznac [24.03.2015].

Profil nauczyciela edukacji włączającej, Europejska Agencja Rozwoju Edukacji Uczniów ze Specjalnymi Potrzebami, Odense 2012.https://www.european-agency.org/ sites/default/files/te4i-profile-of-inclusive-teachers_Profile-of-Inclusive-TeachersPL.pdf [22.03.2015]. 
Raport GUS - Oświata $i$ wychowanie w roku szkolnym 2010/11, http://stat.gov.pl/ cps/rde/xbcr/gus/e_oswiata_i_wychowanie_2010-2011.pdf [12.07.2015]

System Informacji Oświatowej (SIO) rok szkolny 2014/15 publikowanych na stronie Centrum Informatycznego Edukacji http://www.cie.men.gov.pl/index.php/ dane-statystyczne/139.html) [12.07.2015].

Wczesna, Wielospecjalistyczna, Kompleksowa, Skoordynowana i Ciagła Pomoc Dziecku Zagrożonemu Niepetnosprawnością lub Niepetnosprawnemu oraz Jego Rodzinie https://ar chiwum.men.gov.pl/index.php?option $=$ com_content\&view $=$ article\&id $=446 \% 3$ Aqwczesna-wielospecjalistyczna-kompleksowa-skoordynowana-i-ciga-pomocdziecku-zagroonemu-niepenosprawnoci-lub-niepenosprawnemu-oraz-jego-rodzi nieq\&catid=118\%3Aycie-szkoy-pomoc-psychologiczno-pedagogiczna\&Itemid=155 [23.02.2015].

Wczesna Pomoc Dziecku Niepetnosprawnemu (Raport końcowy WPDN) https:/ /www. pfron.org.pl/ftp/dokumenty/Badania_i_analizy/Raport_koncowy_WPDN_osta teczny.pdf [23.02.2015]. 